\title{
The Impact of Job Satisfaction and Some Demographic Variables on Employee Turnover Intentions
}

\author{
Trust Kabungaidze \& Nomakholwa Mahlatshana \\ Department of Industrial Psychology, University of Fort Hare, South Africa \\ E-mail: kabungaidzetrust@gmail.com,nhlatshi@webmail.com \\ Hlanganipai Ngirande \\ School of Economics and Management, University of Limpopo, South Africa \\ E-mail: hlanganipai@yahoo.com
}

Received: October 11, 2012

Accepted: November 13, $2012 \quad$ Online Published: January 5, 2013

doi:10.5430/ijba.v4n1p53

URL: http://dx.doi.org/10.5430/ijba.v4n1p53

\begin{abstract}
Due to competition for scarce skills, the attraction and retention of teachers in rural schools is probably the biggest challenge in the education sector today. It is imperative for the education department to have knowledge of the impact of job satisfaction and some demographic variables on employee turnover intentions to improve the attraction and retention of teachers especially those with scarce skills. Self administered questionnaires were distributed to a sample of 300 teachers. A stratified sampling procedure was utilised. The data was subjected to a number of statistical analyses such as T-test of independent samples, Correlation, Chi-square and One way ANOVA. Results indicated that lack of job satisfaction influences the decision to quit the teaching profession. It also was found that age, tenure and specialization can predict employee turnover intentions. The findings of this research indicate that school authorities need to develop strategies to deal with the needs of those teachers who experience less job satisfaction and commitment. Proactive attention to this should demonstrate preparedness on the side of school administrators to address teacher concerns and thereby reduce absenteeism and attrition rates amongst teachers.
\end{abstract}

Keywords: Demographic variables, Turnover intentions \& teachers

\section{Introduction and Background of the Study}

Concerns about teacher turnover and attrition are reported widely as a global complex phenomenon. In Britain, teacher attrition is reported as a national crisis (BBC News Online, 2001; BBC News, 2001). According to Santiago (2001), the situation is worsening in Sweden, Germany and New Zealand. In the USA, teacher shortages as a result of turnover are widely reported in many states (Markley, 2001 \& Ingersoll, 2002). The Canadian Teachers' Federation (1999) reports on teacher shortages resultant from teacher attrition in Ontario and Australia. In most African countries, the phenomenon of teacher turnover is associated mainly with the HIV/AIDS epidemic, especially in sub- Saharan countries like Zambia, Kenya, Nigeria, the Central African Republic and South Africa (Coombe, 2002). In addition, the President of the Gambian Teachers' Union reports a massive exit of teachers from the profession due to, amongst other reasons, a lack of adequate salaries, allowances, housing and promotion (Kamara, 2002). For instance, Mukumbira (2001) noted that Zimbabwe lost about 2000 newly-qualified teachers who may have left for greener pastures in 2000.

In South Africa, concerns about teacher shortages are beginning to be articulated strongly. In a speech before Parliament to support World Teachers' Day on October 5 in 2002, the Minister of Education, Professor Kader Asmal passionately urged students to study to become teachers, assuring them not to fear retrenchments and further instability in respect of appointments following the termination of the agreement on rationalization and redeployment (City Varsity, 2002). The Minister repeated this plea in his address on releasing Senior Certificate results for 2002 (Asmal, 2002). The minister in particular, appealed to students to take up careers in the teaching profession especially those students who have also done well in Mathematics and Physical Science. The main aim is to address a concern over one of the consequences of teacher turnover, that is, teacher shortages. 
However, the situation regarding teacher turnover and attrition in South Africa seems complex due to a variety of factors. For instance, the need for rationalisation and restructuring has resulted in offers of severance packages, rumours of retrenchments, redeployment of 'excess' teachers in schools and widespread resignations from the profession (Anon, 1998). Enrolments in teacher training colleges have declined drastically, thereby spurring concerns for teacher shortages (Pretorius \& Heard, 1999). On the other hand, it is reported that many vacant teaching posts are not filled (Pretorius \& Heard, 1999; Anon., 2002a; Anon., 2002b). The employment of temporary teachers and the non-filling of permanent posts also point to teacher shortages in South Africa (Carlisle, 2001). Gauteng Department of Education (2002) reports that in Gauteng there is a negative growth rate of the permanent educator corps and that there are more permanent educators.

Another troubling factor is the large-scale exodus of teachers being recruited to schools in London. Many teachers are reportedly leaving the profession for greener financial pastures in countries like Britain (Simpson, 2002). Pillay (2001) reports that British agencies are aggressively poaching South Africans to address the severe teacher shortage in that country, with at least 4000 teachers making their way into Britain since 1994 (cf. Anon., 2001). This implies that teaching expertise in Mathematics and Science is leaving South Africa fast and several local schools are battling to fill posts ( $c f$. Anon., 2001).

On the other hand, the employment of temporary teachers, threats of retrenchments (Naidu, 2001), more primary teachers in the system compared to secondary teachers (Garson, 1995), and the redeployment of excess educators in schools, all seem to suggest that the supply of educators is adequate and the apparent shortage is due to an unequal distribution of teachers in the country (Garson, 1995). According to Osmond (2001), some graduates in the teaching profession are failing to secure jobs because the department does not hire teachers who are not on the excess and redeployment list. As a result these graduates end up considering leaving the country for elsewhere, where their qualifications will be utilised. In support, Maseko (2001) also found out that recently-graduated teachers have, in some cases, been unemployed for up to five years since graduation ( $c f$. O'Connor, 2002).

The foregoing exposition strongly points to a link between teacher demand and supply and teacher turnover. It appears that there could be a shortage of educators in real terms in South Africa, albeit in some curriculum areas only. It also appears that turnover is a reality, even if not easily recognisable, due to the apparently conflicting views expressed above. Teacher turnover manifests itself in many ways and is attributed to many causes. It is therefore imperative that the education system takes cognisance of this and takes steps to address this situation proactively before it reaches critical proportions. This study therefore investigated teacher turnover as a phenomenon to be managed and suggests ways of doing so.

A study by Perrachione, Rosser and Petersen (2008), found out that, race, low job satisfaction and commitment to the profession influence teachers' intention to leave the teaching profession. Building upon this finding, this study intended to examine whether there was any relationship between the job satisfaction levels of teachers and certain demographic variables on teachers' intention to leave the profession in the Butterworth District. Butterworth district is located in Eastern Cape Province. The province has a rural nature and it is the most populated and poorest province in South Africa.

\section{Statement of the Problem}

With the current shortage of teachers in most public schools, coupled with high demand of the "critical" subject teachers, that is, teachers for Mathematics, Physical Sciences and English, the Department of Education is facing a challenge of losing those educators that are already in the field. More than $54 \%$ teachers are leaving the teaching profession (Govender, 2005). The situation regarding teacher turnover and attrition in South Africa seems complex due to a variety of factors. Among other factors, lack of job satisfaction is one of the major contributing factors in teacher turnover. Many studies have tried to establish the role of job satisfaction and certain demographic variables as forerunners of teachers' turnover intentions, but the results have been largely inconclusive (Catalyst, 1999; Finn, 1997; Osborne, 2002). The present study seeks to take this work a step forward by further investigating the relationship between teachers' turnover intentions and job satisfaction factors and demographic variables. The demographic variables concerned are gender, age, level of education, tenure and area of specialization (subjects being taught) and level of grades being taught.

\section{Research Objectives}

- To investigate which job satisfaction factors have an influence on the teachers' intention to leave their profession; 
- To investigate the impact of job satisfaction and some demographic variables (age, gender, area of specialization and tenure) on employee turnover intentions;

- To examine whether there is any relationship between the job satisfaction level of teachers and certain demographic variables and turnover intentions;

- To provide recommendations on strategies that the education department can use to attract and retain teachers based on the research findings.

\section{Hypothesis}

This study postulated that:

H1: Highly satisfied teachers have low levels of intention to leave their profession;

$\mathrm{H} 2$ : There is a significant additive relationship between age, tenure and area of specialisation, on the one hand, and job satisfaction, on the other hand on the intention of teachers to leave their profession.

\section{Research Methodology}

A quantitative research design was used. The researchers utilised a quantitative approach because, as noted by Leedy (2001), quantitative research design allows the researcher to answer questions about the relationships between measured variables with the purpose of explaining, predicting and controlling certain phenomena. In addition to that, Blanche et al. (2007) also found that findings obtained from quantitative research are generalisable and the data is objective.

\subsection{Population of the Study}

The population consisted of all teachers in the selected schools in the Eastern Cape Province of South Africa. According to McClendon (2004) the population of the study is the total number of possible units or elements that are included in the study. It is the aggregate of all units that have a chance of being included in the sample to be studied. A sample of 300 respondents was used in this study. To successfully conduct the research, stratified random sampling method was utilised. Stratified random sampling, according to Saunders, Lewis and Thornhill (2003), is a modification of random sampling in which you divide the whole population into two or more strata based on one or more attributes. In this study, teachers were divided according to departments. Each department represents a stratum. To ensure that samples adequately represent the relevant strata (departments), respondents were randomly selected from within each stratum, that is, from each department

\subsection{Data Collection}

Based on literature review and research objectives, a structured questionnaire was used to collect data. Babbie and Mouton (2005) define a questionnaire as a document containing questions and other types of items designed to solicit information appropriate to analysis. Questionnaires were used because:

- They translate the research objectives into specific questions that are asked of the respondents.

- They also standardise the questions, and response categories, so that every participant responds to identical stimuli.

- They speed up the process of data analysis as all the respondents are asked the same questions.

- They are less expensive and offer greater anonymity.

\subsection{Research Questionnaire of the Study}

The study investigated job satisfaction and demographic variables on the intention of teachers to leave their profession. Three variables were tested in the study, viz. job satisfaction, demographic variables and the intention to leave. The factors that affect job satisfaction were measured by adopting items from the Minnesota Satisfaction Questionnaire (MSQ). The shortened version of MSQ consisting of 20 items was used. The participants were asked to rate the extent to which they agree with each item on a five-point likert scale ranging from very dissatisfied (1) to very satisfied (5). The MSQ has been widely used as a tool for measuring job satisfaction with reliable and valid results. A meta-analysis of MSQ found the overall mean correlation of 0,67 and the reliability ranging from 0,45 to 0,69 (Wanous, Reishers, \& Michael,1997).

The Biographical Questionnaire was used to collect data pertaining to the second variable, namely demographic variables. Such demographic variables to be tested include age, gender, marital status, school area, teaching experience, qualifications rank and the grade taught. 
Data for the third variable, that is, the intention to leave the profession was gathered using the Intention to Leave Questionnaire. The participants were requested to rate the extent to which particular factors related to job satisfaction, have an influence on their intention to leave their profession. The three questionnaires were consolidated into one questionnaire divided into sections. The first section was constructed around some demographic variables and second section dealt with the basic job elements of teachers which include, teaching, community service, administration and own management, compensation and job security, promotions, management and leadership, relationship with co-workers and a lot more.

\subsection{Administering the Questionnaire}

Once a questionnaire is designed, pilot tested and amended, the questionnaire can be used to collect data. There are various ways available for administering a questionnaire. Examples of these ways include postal questionnaires, online questionnaires and self-administering the questionnaire (Saunders, et al., 2003). According to Kumar (2005), postal questionnaires involve sending the questionnaire to prospective respondents by mail. The approach pre-supposes that the researcher has access to each respondent's address. Usually a self-addressed envelope and a covering letter accompany the questionnaire. However, this approach of questionnaire administering has its limitations. One of the limitations is that it has a low response rate since the researcher does not have direct contact with the respondents. According to Saunders et al. (2003), online questionnaires are usually administered through emailing or via a website. A good response rate using this method depends on the recipient being motivated to answer the questionnaire and return it (Saunders, et al., 2003). This approach has a disadvantage in that not all members in a given sample may have access to the internet or may know how to use it.

In this study researchers self-administered the questionnaire and the following procedure was followed;

- The researcher personally discussed the administration of the questionnaire with the school principals from each school. Questionnaires were distributed during tea breaks to avoid teaching disturbances. Offices numbers under each department were used to stratify the sample;

- A total number of 300 were distributed. Discussions were held with the school principals officials to stress the anonymity and confidentiality of the information and how each official was suppose to stress these issues to the respondents as well;

- To achieve a possible high response rate, it was agreed that the data collection period be a maximum of six weeks;

- A follow-up strategy was discussed with respective school principals. It was agreed that the school principals would make internal follow ups every week and the researcher would go and collect the completed questionnaires after every two weeks

The researcher utilised this method because it is less expensive, ensures the anonymity of the respondents and has a high respondent completion return rate as the researcher can make follow-ups for unreturned questionnaires. The main advantage of this procedure is that the researcher or a member of the research team can collect all the completed responses within a short period of time (Sekaran, 2003). Out of the 300 questionnaires distributed, 219 were returned. The response rate was 73 percent.

\section{Data Analysis}

The research utilised quantitative techniques of data analysis. Babbie and Mouton (2005) define quantitative analysis as the numerical representation and manipulation of observations for the purpose of describing and explaining the phenomena that those observations reflect. All data obtained from the respondents was analyzed using descriptive inferential statistical analysis, which includes the mean, standard deviation and the variance of the respondents' scores in summarizing data. The Statistical Package for the Social Sciences (SPSS) program was used to analyze data. Demographic data was reported by using frequencies and percentages. The T-test was used to test the relationship between gender and turnover intentions. Chi-Square was also used to determine the association between variables. One way ANOVA was used to test the significance level of relationship between variables. Correlation was used to determine the direction and strength of the relationship between variables.

\section{Research Findings}

\subsection{Inferential Statistics}

In order to test the contribution of the independent variables (job satisfaction and certain demographic variables) to the dependent variable (turnover intentions), several statistical models were used. These include the Chi-Square to test whether there is an association between independent and dependent variables, Anova to test the significance of 
the association and Pearson Correlation to test the strength and direction of the relationship between variables. A Chi-square was used to determine whether there was an association between certain demographic factors and turnover intentions. Results from the analysis indicated that age, tenure and specialisation can predict turnover intentions. The results are shown below.

\section{Chi-Square Tests}

$<$ Insert Table 1 Here $>$

A Chi-square test of association was performed by cross tabulating two variables namely age and turnover intentions. Results from Table 1 shows a chi-square value of $33.512^{\mathrm{a}}$ and 48 degrees of freedom with a probability value of 0.006 . Since the p-value is less than 0.05 , it therefore means that we accept the null hypothesis and conclude that age can predict turnover intentions. To determine the direction of the association, one way Anova was used.

\section{Test of homogeneity of variances}

$<$ Insert Table 2 Here $>$

The homogeneity of variance option provides a Levene's test for homogeneity of variances, which tests whether the variance in scores is the same for each of the five groups. If the value is greater than 0.05 the assumption of homogeneity of variance is not violated. In this case it is 0.377 .

\section{One way Anova test: Relationship between age and turnover intentions}

$<$ Insert Table 3 Here $>$

Table 3 indicates a relationship between age and turnover intentions. The results are as shown below.

\section{Correlations: The strength and direction of the relationship between age and turnover intentions}

$<$ Insert Table 4 Here $>$

Pearson Correlation analysis was used to determine the strength and direction of the relationship. Pearson Correlation analysis was used to determine the strength and direction of the relationship. Correlation is a technique for investigating the relationship between two quantitative, continuous variables, for example, age and turnover intentions. Pearson's correlation coefficient ( $r$ ) is a measure of the strength of the association between the two variables. Table 4 shows that there is a negative relationship between age and turnover intentions $(\mathrm{r}=-0.183$, $\mathrm{p}=0.006$ ). This means the greater the age cohort, the lesser the turnover intentions. In this case, older employees between the age group of 45 years and above experience less turnover intentions.

\section{Tenure and Turnover intentions}

The results from Table 5 (Chi-square analysis) below indicate that there is a strong association between tenure and turnover intentions. A Chi-square test of association was performed by cross tabulating two variables namely, tenure and turnover intentions. From the results we got a Chi-square value of $93.422^{\mathrm{a}}$ and 48 degrees of freedom with a probability value of 0.000 . Since the p-value is less than 0.05 , it therefore means that we accept the null hypothesis and conclude that area of tenure can predict turnover intentions. In other words, the number of years can actually determine the turnover intentions. To determine the significance of this association, on way Anova was used.

\section{Chi-Square Tests}

$<$ Insert Table 5 Here $>$

\section{One way ANOVA}

$<$ Insert Table 6 Here $>$

The analysis shows that there is a significant relationship between tenure and turnover intentions. Pearson correlation was used to determine the strength and direction of the relationship.

\section{Correlations: Strength and direction of the relationship between tenure and turnover intentions}

$<$ Insert Table 7 Here $>$

Pearson Correlation analysis was used to determine the strength and direction of the relationship between turnover intentions and tenure. Correlation is a technique for investigating the relationship between two quantitative, continuous variables, for example, tenure and turnover intentions. Pearson's correlation coefficient (r) is a measure of the strength of the association between the two variables. Table 7 shows that there is a negative relationship between tenure and turnover intentions $(\mathrm{r}=-0.206, \mathrm{p}=0.002)$. This means the greater the number of years teaching at the same school, the lesser the turnover intentions as shown in Table 8 below. 


\section{Association between specialization and turnover intentions}

$<$ Insert Table 8 Here $>$

A Chi-square test of association was performed by cross tabulating two variables namely specialisation and turnover intentions. From the results we got a chi-square value of $63.031^{\mathrm{a}}$ and 48 degrees of freedom with a probability value of 0.007 . Since the p-value is less than 0.05 , it therefore means that we accept the null hypothesis and conclude that area of specialisation can predict turnover intentions.

\section{Test of Homogeneity of Variances}

$<$ Insert Table 9 Here $>$

The homogeneity of variance option provides a Levene's test for homogeneity of variances, which tests whether the variance in scores is the same for each of the five groups. If the value is greater than 0.05 the assumption of homogeneity of variance is not violated. In this case it is 0.573 .

One way Anova results of the relationship between area of specialization and turnover intentions

$<$ Insert Table 10 Here $>$

Results from Table 10 above indicate that there is a significant difference in specialisation and turnover intentions.

\section{Correlation between area of specialization and turnover intentions}

Pearson Correlation analysis was used to determine the strength and direction of the relationship. Correlation is a technique for investigating the relationship between two quantitative, continuous variables, for example, area of specialisation and turnover intentions. Pearson's correlation coefficient ( $r$ ) is a measure of the strength of the association between the two variables. Table 12 shows that there is a negative relationship between area of specialization and turnover intentions $(\mathrm{r}=-0.095, \mathrm{p}=0.016)$. This means that code $(2)$ in the instrument (sciences) is associated with high turnover over intentions than code 4 and 5 which represents teachers in humanities and languages. The high turnover intentions can be attributed to the fact that science as a discipline, is in high demand and people can hope from one organisation to another since they possess scarce skills that are in demand as shown in Table 11 below.

$<$ Insert Table 11 Here $>$

\section{Chi-Square results showing the association between job satisfaction and turnover intentions}

A chi-square test of association was performed by cross tabulating two variables namely job satisfaction and turnover intentions. From the results we got a chi-square value of $666.314^{\mathrm{a}}$ and 576 degrees of freedom with a probability value of 0.005 . Since the p-value is less than 0.05 , it therefore means that we accept the null hypothesis and conclude that satisfied teachers have low turnover intentions as depicted in Table 12 below.

$<$ Insert Table 12 Here>

In addition to the Chi-square test of association, Pearson Correlation analysis was carried to determine significance of the relationship between job satisfaction and turnover intentions.

$<$ Insert Table 13 Here>

Results from the correlation analysis indicates a negative relationship between job satisfaction and turnover intentions $(r=-0.182, p=0.007)$ meaning the more satisfied the teachers are, the less they experience job turnover intentions.

It was also important to test the overall mean of turnover intentions in order to determine whether teachers were likely to stay or leave the profession in future. The overall turnover mean was 3.39726. This indicates that respondents (teachers) were uncertain of staying or leaving the teaching profession. The is as a result of teachers being exposed to both job satisfying factors such freedom to plan, high degree of initiative and on the other hand being exposed to dissatisfying factors such as lack of conscience in doing work, poor working conditions, the rural nature of the province and a lot more. Consequently, teachers are not sure whether they are totally satisfied or dissatisfied.

\section{Discussion}

It will be recalled that the purpose of this study was to investigate the impact of job satisfaction and certain demographic factors on employee turnover. It was hypothesized that highly satisfied teachers have no intentions to leave the teaching profession. It was also hypothesized that certain demographic factors predict employee turnover 
intentions. This chapter provides a discussion of the findings of the study and seeks to answer the research questions of the study.

This chapter provides an overview of salient research findings emanating from the research. In order to contextualise the research, comparisons are drawn with available literature on job satisfaction and turnover intentions amongst teachers. The chapter provides conclusions that can be drawn from the research and offers suggestions for future research into job satisfaction and turnover intentions amongst teachers.

\subsection{Inferential Statistics}

Research question: What is the impact of job satisfaction and certain demographic factors on teachers' turnover intentions?

\subsection{Age and Turnover Intentions}

The results from Table 4 shows that there is a negative relationship between age and turnover intentions $(\mathrm{r}=-0.182$, $\mathrm{p}=0.007)$. This means the greater the age cohort the lesser the turnover intentions. In this case, older teachers between the age group of 45 years and above experience less turnover intentions than teachers below the age of 25 years. Based on a review of literature on age, Rhodes (1983) concluded that overall job satisfaction is related to age. Older workers appear to evidence greater satisfaction with their employment than younger workers. Hence older teachers usually stay in the profession for a longer period than younger teachers. While many researchers suggest a linear relationship (Mottaz, 1987; Weaver, 1980), other studies (Kacmar, Carlson \& Brymer, 1999) report a U shaped relationship. Clark (1996) provided explanations for the U-shaped relationship between job satisfaction and age. Clark (1996) suggested that younger workers may feel satisfied because they have little experience about the labour market against which to judge their own work. Clark (1996) noted that older workers may have reduced aspirations as they realise that they face limited alternative choices as they get older. Loscocco (1990) similarly suggests that job satisfaction increases until age 40, then levels off, and then finally increases again when employees reach their late fifties.

Bishay (1996) investigated teacher motivation and satisfaction amongst a sample of 120 teachers. Results from this study indicate that job satisfaction seems to increase with age and years of service. Blood et al (2002) research amongst a sample of 1320 teachers in public schools indicated that older teachers were more likely to report higher levels of job satisfaction than younger teachers.

Blood et al (2002) maintain that it is plausible that older workers are more comfortable and tolerant of authority and may learn to lower expectations for their jobs. Spector (1997) proffers the view that older workers may have jobs that use their skills better, work under better job conditions, benefit from advancements and promotions, and appreciate fringe benefits more than younger, less experienced employees.

\subsection{Tenure and Turnover Intentions}

The results of the current research indicate that there is a statistically significant relationship between tenure and turnover intentions amongst teachers from disadvantaged schools in the Eastern Cape. Results in Table 8 shows that there is a negative relationship between tenure and turnover intentions $(r=-0.206, p=0.002)$. This means the greater the number of years teaching at the same school the lesser the turnover intentions. Based on sample of 1320 public school teachers Blood et al. (2002) also demonstrated that there is a statistically significant relationship between tenure and job satisfaction. Their research indicated that the longer teachers remained in their jobs, the more likely they were to report higher levels of job satisfaction and lower levels of turnover intentions. In support of the current findings, Reyes (2001) conducted research on 133 teachers to establish the relationship between individual work orientations and teacher outcomes. The results emanating from the research indicate that there is a statistically significant relationship between job satisfactions based on tenure. Reyes (2001) maintains that this relationship is strong because dissatisfied teachers may leave the profession before spending several years on the job.

\subsection{Area of Specialization and Turnover Intentions}

The results of the current research indicate that there is a statistically significant relationship between area of specialization and turnover intentions amongst teachers from disadvantaged schools in the Eastern Cape. Results in Table 12 show that there is a negative relationship between area of specialization and turnover intentions $(\mathrm{r}=-0.095$, $\mathrm{p}=0.016$ ). This means that code (2) in the instrument (sciences) is associated with high turnover over intentions than code 4 and 5 which represents teachers in humanities and languages. The high turnover intentions can be attributed to the fact that science as a discipline, is in high demand and people can hope from one organisation to another since they possess scarce skills that are in demand. 


\subsection{Job Satisfaction and Turnover Intentions}

Results from the current study indicates a negative relationship between job satisfaction and turnover intentions $(\mathrm{r}=-0.182, \mathrm{p}=0.007)$ meaning the more satisfied the teachers are, the less they experience job turnover intentions.

It was also important to test the overall mean of turnover intentions in order to determine whether teachers were likely to stay or leave the profession in future. The overall turnover mean was 3.39726. This indicates that respondents (teachers) were uncertain of staying or leaving the teaching profession. The is as a result of teachers being exposed to both job satisfying factors such as freedom to plan, high degree of initiative and on the other hand being exposed to dissatisfying factors such as lack of conscience in doing work, poor working conditions, the rural nature of the province and a lot more. Consequently, teachers are not sure whether they are totally satisfied or dissatisfied.

\section{Conclusions}

The aim of this research was to primarily determine the impact of job satisfaction and certain demographic variables on turnover intentions amongst teachers from rural and semi-rural schools in the Eastern Cape. The results emanating from the research indicate there is a statistically significant relationship between job satisfaction and turnover intentions among the sample of teachers selected to participate in the research. A negative relationship was found. This means the higher the job satisfaction the lower the turnover intentions. From the results, it can be deduced that highly satisfied teachers stay in their profession and the null hypothesis is accepted.

Moreover, there was a statistically significant relationship between the certain demographic variables (age, tenure and area of specialization) and turnover intentions. Age, tenure and specialization can predict employee turnover intentions. A negative relationship was found between age and turnover intentions. Since the p-value was less than 0.05 it therefore means that we accept the null hypothesis and conclude that age can predict turnover intentions. In other words, employees with more than 45 years experience the lower the level of turnover intentions. In terms of the association between tenure and turnover intentions, the p-value was less than 0.05 , it therefore means that we accept the null hypothesis and conclude that area of tenure can predict turnover intentions. In other words, the number of years can actually determine the turnover intentions. Lastly, it can be concluded that area of specialization can predict turnover intentions. Teachers specializing in science subjects recorded higher levels of turnover intentions than other teachers. This means that science teachers are likely to leave their profession and join other professions than those teaching languages and humanities. This is because science teachers possess scarce skills that are in demand in other sectors other than the education sector.

\section{Recommendations}

The findings of this research indicate that school authorities need to develop strategies to deal with the needs of those teachers who experience less job satisfaction and commitment. Proactive attention to this should demonstrate preparedness on the side of school administrators to address teacher concerns and thereby reduce absenteeism and attrition rates amongst teachers.

Notwithstanding the limitations of the current research, a number of recommendations for future research are suggested. Priorities for future research include controlling for extraneous and confounding variables which would simultaneously improve the internal validity of the research. A more rigorous research design could have facilitated this. Ideally a larger sample based on a stratified random design could be drawn. This is because stratified random sampling is argued to minimise sampling errors and enhance the external validity of research findings (Sekaran, 2003). Consequently, it allows for results to be extrapolated from the sample to the population with greater confidence.

The differences between teacher job satisfaction and turnover intentions in urban, suburban and rural schools should be explored (Steyn \& van Wyk, 1999). Haughey and Murphy (1983) found, for example that nearly 50\% of rural teachers were somewhat dissatisfied with their working conditions compared to only $3.45 \%$ of those professionals in suburban schools.

Culver, Wolfe and Cross (1990) argue that it would be valuable to determine if the processes leading to teacher satisfaction are similar or different during the various stages of teachers' careers. Similarly, this could be applied to their organisational commitment levels. Mwamwenda, (1995) recommended that knowledge gained in this topic may guide educational decision-makers in nurturing the professional well-being of teachers and that in turn may lead to improving teaching practices. Given the far-reaching changes in the South African education milieu, the impact of job satisfaction and demographic factors on turnover intentions should be explored further. 


\section{References}

Anon. (1998). Education crisis unresolved. The Educators' Voice. [Online] Available: http://www.sadtu.org.za

Anon. (2001). Shrinking supply of suitable staff. The Teacher/Mail \&Guardian. [Online] Available: http://www.teacher.co.za

Anon. (2002a). Drop in number studying teaching could result in crisis for the future. [Online] Available: http://www.cityvar sity.co.za

Anon. (2002b). There is only one training college left in the Western Cape which is being phased out. [Online] Available: http://www.cityvar sity.co.za

Asmal, K. (2002). Speech by Professor Kader Asmal, MP, Minister of Education on the release of 2002 Senior Certificate Examination Results. Good hope Auditorium: Cape Town.

Babbie, E., \& Mouton, J. (2005). The Practice of Social Research. Cape Town: Oxford University Press.

BBC News Online. (2001). Teacher shortage a 'national crisis'. January 18. [Online] Available: http://news.bbc.co.uk.

BBC News. (2001). Truth about teacher shortages. [Online] Available: http://news.bbc.com

Bishay, A. (1996). Teacher motivation and job satisfaction: A study employing the experience sampling method. Journal of Undergraduate Sciences, 3, 147- 154.

Blood, G., Ridenour, J., Thomas, E., Qualls, C., \& Hammer, C. (2002). Predicting job satisfaction among speech-language pathologists working in public schools. Language, Speech and Hearing Services in Schools, 33, 282- 290.

Carlisle, A. (2001). 2000 teaching posts vacant in EC. Dispatch online. [Online] Available: http://www.dispatch.co.za

Catalyst. (1999). W hat high-turnover schools have in common. [Online] Available: http://www.catalyst-chicago.org

City Varsity. (2002). There is hope for those wanting to be teachers. [Online] Available: http://www.cityvarsity.co.za Clark, A., \& Oswald, A. (1996). Satisfaction and comparison income. Journal of Public Economics, 61, 359-381.

Coombe, C. (2002). Keeping the education system healthy: Managing the impact of HIV/AIDS on education in South Africa. Current Issues in Comparative Education, 3.

Culver, S., Wolfe, L., \& Cross, L. (1990). Testing a model of teacher satisfaction for Blacks and Whites. American Educational Journal, 27, 323-349.

Finn. C.E. (1997). The real teacher crisis. Education Week. [Online] Available: http://www.edexcellence.net/library/rlteach.html

Garson, P. (1995). Teacher training fails the test. Mail \& Guardian, December 8.

Govender, P. (2005, October 23). SA teachers teach only half the time. Sunday Times, p.8.

Haughey, M., \& Murphy, P. (1983). Are rural teachers satisfied with the quality of their work life? Education, 104, 56-66.

Ingersoll, R.M. (2002). The teacher shortage: A case of wrong diagnosis and wrong perception. NASSP Bulletin, 86.

Kacmar, K.M., Carlson, D.S., \& Brymer, R.A. (1989). Antecedents and consequences of organisational commitment: A comparison of two scales. Educational \& Psychological Measurement, 59(6), 976-995.

Kamara, F. (2002). As acute teacher shortage hits countrywide GTU president speak out. The Daily Observer. [Online] Available: http://allafrica.com

Kumar, R. (2005). Research Methodology. London: Sage Publications.

Leedy, P. (2001). Research Planning and Designing (4th ed.). London: Sage.

Loscocco, K.A. (1990). Reactions to blue-collar work: A comparison of women and men. Work \& Occupations, 17(2), 152-178.

Markely, M. (2001). Districts taking new steps to stem teacher turnover. Houston Chronicle.com. [Online] Available: http://www.chron.com 
Maseko, T. (2001). Thuthuka Maseko presents alternatives to redeployment for teachers. The Teacher/Mail \& Guardian.

McClendon, M.J. (2004). Statistical Analysis in Social Sciences. Victoria: Thomson Wadsworth.

Mottaz, C.J. (1987). Age and work satisfaction. Work and Occupation, 14, 387-409.

Mukumbira, R. (2001). Zim loses 2000 teachers. News 24.com. [Online] Available: http://www.news24.com/News24/ Zimbabwe

Mwamwenda, T.S. (1995). Job satisfaction among secondary school teachers in Transkei. South African Journal of Education, 15(2), 84-86.

Naidu, E. (2001). Number of new teachers dwindling. The Teacher/Mail \& Guardian. [Online] Availabl: http://www.teacher.co.za/200102/tertiary.html

O'Connor, S. (2003). W ho wants to be a teacher? The Teacher/Mail \& Guardian. [Online] Available: http://www.teacher.co.za/20 0009/trainee

Osborne, H. (2002). Teacher turnover. St Helena Star. [Online] Available: http://www.sthelenastar.com/5-30-02/headlines/teacher.html

Osmond, M. (2001). Forced to go. The Teacher/Mail \& Guardian. [Online] Available: http://www.teacher.co.za/200106/01 -letters.html

Perrachione, B.A., Rosser, V.J., \& Petersen,G. J. (2008). Why Do They Stay? Elementary Teachers' Perceptions of Job Satisfaction and Retention, 32, 2.

Pillay, R. (2001). Top teachers headhunted by UK agencies. Mail \& Guardian. February 2001.

Pretorius, C., \& Heard, J. (1999). Shock teacher shortage looms: Dramatic fall in enrolments at training institutions will trigger education crisis within two years. New Jersey.

Reyes, P. (2001). Individual work orientations and teacher outcomes. Journal of Educational Research, 83(6), 327-335.

Santiago, P. (2001). Teacher shortage. Observer OECD. [Online] Available: http://www.oecdobserver.org/news/printpage.php/aid /431/Teacher_shortage.html

Saunders, M., Lewis, P., \& Thornhill, A. (2003). Research Methods for Business Students (3 ${ }^{\text {rd }}$ ed.). England: Prentice Hall.

Sekaran, U. (2003). Research methods for business: A skill-building approach (3rd ed.). New York: John Wiley \& Sons, Inc.

Simpson, M. (2002). It pays to move to greener pastures. The Teacher. [Online] Available: http://www.teacher.co.za/cms/article_2002_11_28_2311.html

Spector, P.E. (1997). Job satisfaction: Application, assessment, cause, and consequences. Thousand Oaks, CA: Sage Publications, Inc.

Steyn, G.M., \& van Wyk, J.N. (1999). Job satisfaction: Perceptions of principals and teachers in urban black schools in South Africa. South African Journal of Education, 19(1), 37-43.

Weaver, C.N. (1980). Sex differences in the determinants of job satisfaction. Academy of Management Journal, 21, 265-74.

Table 1. Chi-Square test showing the association between age and turnover intentions

\begin{tabular}{|l|l|l|l|}
\hline & Value & Df & $\begin{array}{l}\text { Asymp. Sig. } \\
\text { (2-sided) }\end{array}$ \\
\hline Pearson Chi-Square & $33.512^{\mathrm{a}}$ & 16 & .006 \\
Likelihood Ratio & 37.729 & 16 & .002 \\
Linear-by-Linear & 7.626 & 1 & .006 \\
Association & & & \\
N of Valid Cases & 219 & & \\
\hline
\end{tabular}


Table 2. Test of Homogeneity of Variances

\begin{tabular}{|c|c|c|c|}
\hline Levene Statistic & df1 & $\mathrm{df} 2$ & Sig. \\
\hline 1.061 & 4 & 214 & .377 \\
\hline
\end{tabular}

Table 3. Relationship between age and turnover intentions

\begin{tabular}{|l|l|l|l|l|l|}
\hline & $\begin{array}{l}\text { Sum of } \\
\text { Squares }\end{array}$ & df & $\begin{array}{l}\text { Mean } \\
\text { Square }\end{array}$ & F & Sig. \\
\hline $\begin{array}{l}\text { Between } \\
\text { Groups } \\
\text { Within } \\
\text { Groups }\end{array}$ & 25.106 & 4 & 6.277 & 4.428 & .002 \\
Total & 303.332 & 214 & 1.417 & & \\
\hline
\end{tabular}

Table 4. The strength and direction of the relationship between age and turnover intentions

\begin{tabular}{|ll|r|r|}
\hline & \multicolumn{1}{|c|}{$\begin{array}{c}\text { Mean } \\
\text { Turnover } \\
\text { intentions }\end{array}$} & Mean Age \\
\hline $\begin{array}{l}\text { an Turnover } \\
\text { intentions }\end{array}$ & Pearson Correlation & 1 & $-.183^{* *}$ \\
& Sig. (2-tailed) & & .006 \\
& $\mathrm{~N}$ & 219 & 219 \\
\hline
\end{tabular}

Table 5. Chi-Square test showing the association between tenure and turnover intentions

\begin{tabular}{|l|r|r|r|}
\hline & Value & df & Asymp. Sig. (2-sided) \\
\hline Pearson Chi-Square & $93.422^{\mathrm{a}}$ & 48 & .000 \\
\hline Likelihood Ratio & 102.436 & 48 & .000 \\
\hline $\begin{array}{l}\text { Linear-by-Linear } \\
\text { Association }\end{array}$ & 11.584 & 1 & .001 \\
\hline N of Valid Cases & 219 & & \\
\hline
\end{tabular}

Table 6. One way Anova results

\begin{tabular}{|c|c|c|c|c|c|}
\hline & Sum of Squares & Df & Mean Square & $\mathrm{F}$ & Sig. \\
\hline Between Groups & 17.169 & 4 & 4.292 & 2.951 & .021 \\
\hline Within Groups & 311.269 & 214 & 1.455 & & \\
\hline Total & 328.438 & 218 & & & \\
\hline
\end{tabular}


Table 7. The relationship between tenure and turnover intentions

\begin{tabular}{|ll|r|r|}
\hline & & $\begin{array}{r}\text { Turnover } \\
\text { intentions }\end{array}$ & Tenure \\
\hline $\begin{array}{l}\text { Turnover } \\
\text { intentions }\end{array}$ & Correlation & 1 & $-.206^{* *}$ \\
& Sig. (2-tailed) & & .002 \\
& $\mathrm{~N}$ & 219 & 219 \\
\hline Tenure $\quad$ Pearson Correlation & $-.206^{* *}$ & 1 \\
& Sig. (2-tailed) & .002 & \\
& $\mathrm{~N}$ & 219 & 219 \\
\hline
\end{tabular}

Table 8 . Association between specialization and turnover intentions

\begin{tabular}{|c|c|c|c|}
\hline & Value & $\mathrm{df}$ & $\begin{array}{l}\text { Asymp. Sig. } \\
\text { (2-sided) }\end{array}$ \\
\hline Pearson Chi-Square & $63.031^{\mathrm{a}}$ & 48 & .007 \\
\hline Likelihood Ratio & 69.706 & 48 & .002 \\
\hline $\begin{array}{l}\text { Linear-by-Linear } \\
\text { Association }\end{array}$ & 1.952 & 1 & .162 \\
\hline $\mathrm{N}$ of Valid Cases & 219 & & \\
\hline
\end{tabular}

Table 9. Test of homogeneity of variances

\begin{tabular}{|c|c|c|c|}
\hline Levene Statistic & df1 & df2 & Sig. \\
\hline .729 & 4 & 214 & .573 \\
\hline
\end{tabular}

Table 10. One way Anova results of the relationship between area of specialization and turnover intentions

\begin{tabular}{|l|r|r|r|r|r|}
\hline & Sum of Squares & Df & Mean Square & F & \multicolumn{1}{c|}{ Sig. } \\
\hline Between Groups & 13.708 & 4 & 3.427 & 2.330 & .037 \\
Within Groups & 314.730 & 214 & 1.471 & & \\
Total & 328.438 & 218 & & & \\
\hline
\end{tabular}


Table 11. Correlation of the relationship between turnover intentions and specialization

\begin{tabular}{|ll|r|r|}
\hline & & $\begin{array}{r}\text { Turnover } \\
\text { intentions }\end{array}$ & Specialisation \\
\hline $\begin{array}{l}\text { Turnover } \\
\text { intentions }\end{array}$ & Pearson Correlation & 1 & -.095 \\
& Sig. (2-tailed) & & .016 \\
& $\mathrm{~N}$ & 219 & 219 \\
\hline Specialisation & Pearson Correlation & -.095 & 1 \\
& Sig. (2-tailed) & .163 & \\
& $\mathrm{~N}$ & 219 & 219 \\
\hline
\end{tabular}

Table 12. Chi-Square results showing the association between job satisfaction and turnover intentions

\begin{tabular}{|c|c|c|c|}
\hline & Value & df & $\begin{array}{l}\text { Asymp. Sig. } \\
\text { (2-sided) }\end{array}$ \\
\hline Pearson Chi-Square & $666.314^{\mathrm{a}}$ & 576 & .005 \\
\hline Likelihood Ratio & 500.855 & 576 & .989 \\
\hline Linear-by-Linear Association & 7.207 & 1 & .007 \\
\hline $\mathrm{N}$ of Valid Cases & 219 & & \\
\hline
\end{tabular}

Table 13. Correlations for job satisfaction and turnover intentions

\begin{tabular}{|c|c|c|c|}
\hline & & $\begin{array}{l}\text { Mean } \\
\text { Turnover } \\
\text { intentions }\end{array}$ & Mean JS \\
\hline \multirow{3}{*}{$\begin{array}{l}\text { Mean Turnover } \\
\text { intentions }\end{array}$} & Pearson Correlation & 1 & $-.182^{* *}$ \\
\hline & Sig. (2-tailed) & & .007 \\
\hline & $\mathrm{N}$ & 219 & 219 \\
\hline \multirow{3}{*}{$\begin{array}{l}\text { Mean Job } \\
\text { Satisfaction }\end{array}$} & Pearson Correlation & $-.182^{* *}$ & 1 \\
\hline & Sig. (2-tailed) & .007 & \\
\hline & $\mathrm{N}$ & 219 & 219 \\
\hline
\end{tabular}

